\title{
Micro Enterprises In Inner-City Communities: Current Challenges And Viability
}

Arup K. Sen, D’Youville College, USA

\begin{abstract}
Supporting micro enterprises within inner-city communities is a viable strategy to promote economic development, combat poverty, and alleviate social costs. Some authors suggest that micro entrepreneurship is essential to maintain a healthy economy within low-income communities. This paper is aimed at highlighting the profile and functioning of micro enterprises in inner-city Buffalo, New York with regards to aspects such as size, financial and non-financial assistance, goals and barriers experienced by micro entrepreneurs. Data from an exploratory survey of 100 micro enterprises suggest that micro entrepreneurs encounter several problems that impact negatively on their profitability and viability. The data also suggests that these entrepreneurs are constrained not only by financial factors but also non-controllable factors such as the economy of the city, availability of reliable labor, and insurance requirements. This paper concludes with a brief discussion of the implications of the survey findings for developing strategies to address issues facing micro enterprises in inner-city communities
\end{abstract}

Keywords: micro-enterprises; entrepreneurship; inner-city

\section{INTRODUCTION}

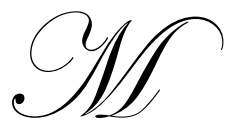

icro enterprises play a significant role in the economic growth of most communities and economies in developed and developing nations. Micro enterprises have also tended to be a strategy in inner-city communities of both developed and developing economies to promote economic development and also to alleviate poverty and social costs such as food stamps and welfare. These enterprises also assist in developing inner-city neighborhoods by creating jobs and a return on investment for the entrepreneurs (Schreiner, 2001).

A micro enterprise business is a small business with usually five or fewer employees that require less than $\$ 35,000$ to start and is too small to qualify for services offered typically by major commercial financial institutions. Typically, these enterprises are informally run businesses involved primarily in retail and service activities. Most of these enterprises have tended to be looked at from a development or poverty alleviation perspective rather than as entrepreneurial activities and potentially growing businesses. Micro enterprises may be further segregated into survival micro enterprises, which include low skilled, low cost as compared to entrepreneurial micro enterprises, which occupies skilled labor, technical knowledge, and greater use of capital. (Shaw, 2004)

While sufficient evidence and analyses of micro financing, development, and training programs exist, there is a paucity of research that examines the financial and non-financial challenges of the inner-city micro enterprise owners. While studies have been conducted that identify micro enterprise programs this paper explores the barriers experienced by these entrepreneurs in terms of their potential for long-term business success and determine owner's level of financial dependence and success factors. There is a lack of systematic information available to determine how these micro enterprises got established, how they perform, what their financial and non-financial requirements are, and what their current challenges are like in the inner-city community of Buffalo, New York. 
Set against this backdrop, the research aims at obtaining more systematic information on the profile of inner-city micro enterprises, financial assistance, barriers facing the establishments and their establishment goals. The paper is organized as follows. The next section provides a research context for this study along with an overview of current theoretical perspectives of micro enterprise activities. Next I describe the survey methodology and the main characteristics of the survey establishments. Following this section, I present the results for the micro enterprise firms surveyed. This paper concludes with a brief discussion of the implications of the survey results for the strategic management of micro businesses.

\section{RESEARCH CONTEXT}

Micro enterprises must exhibit a level of entrepreneurial knowledge in order to survive, as few of these enterprises have the knowledge and financial resources to withstand the competitive pressures. Many social scientists suggest that micro-entrepreneurship is critical for the economic development of inner-city communities, and for economic development to be effective, new businesses in low-income communities must be instituted by local initiatives. (Acs and Malecki, 2003; Lichtenstein and Lyons 2001). According to Hisrich and Peters (1998) entrepreneurship is defined as "the process of creating something new with value by devoting the necessary time and effort, assuming the accompanying financial, psychic, and social risks, and receiving the resulting rewards of monetary and personal satisfaction and independence" (p9). Porter's work on creating wealth within disadvantaged inner-city communities contends that government should focus on providing infrastructure to support genuinely profitable businesses. Porter's model is not aimed to redistribute wealth but "to identify and exploit the competitive advantage of inner-cities that will translate in truly profitable business" (Porter, 1995:56)

The United States census defines a micro enterprise as a business that operates with five or less employees. In New York State about 85 percent of the businesses are classified as micro businesses, which convert to approximately two million micro enterprises, employing a fifth of the State's labor force and generating almost $\$ 60$ billion in annual revenues (Deutsch, 2006). These micro entrepreneurs have minimal savings and their success relies on the availability of financing from commercial financial institutions, micro-loans, or grants. However, because of their lack of any significant collateral, high interest rates, and limited access to financial services, results in a deterrent and barrier for the start-up and survival of these enterprises. (Lichtenstein and Lyons,2001; Jurik et. al., 2006).

Much of the literature on the viability of micro enterprises is either conceptual or anecdotal and has focused primarily on the financing and training programs. (Roger et.al. 2001). The underlying reasons for the disparity in performance of these micro entrepreneurs has resulted because of limited per capita purchasing power and the over representation of these enterprises in a competitive and low profitable type of economic activity such as retail and services ( Suron,1997). For several decades, programs such as the Community Entrepreneurs Program ( CEP) has assisted micro entrepreneurs with strategies to establish and succeed in their business endeavors by providing them with the appropriate education programs, personal empowerment, and asset building (Dumas, 2001). In this study it should be conceded that I am not attempting to contribute to the theoretical discussion of micro enterprises, but instead my focus is empirical, exploratory, and descriptive.

\section{SURVEY METHODOLOGY}

It is a major challenge for researchers in obtaining systematic information from micro enterprises because of lack of current contact information. Experience from past research indicates that micro enterprises are reluctant to respond to mail surveys because of time constraints by the owner of the micro business and also in their understanding and interpretation of some of the terminology in the questionnaire. Because of this, a telephone survey was conducted to obtain data and verbally explained the questions with a standard protocol.

Micro enterprises are defined as business with less than 5 employees that require less than $\$ 35,000$ start-up capital and also too small to receive financial services from a major commercial financial institution. In a preliminary effort to contact the micro-enterprises a telephone survey was conducted with 100 micro business owners located in the inner-city of Buffalo, New York. While the survey data was restricted to only inner-city Buffalo (leaving the analysis rather limited in terms of geographical scope), some of the results suggest potentially useful directions for additional empirical work at an expanded geographical scale. 
In a study by Frey, (1989) the advantages of data gathered by telephone survey far outweigh the disadvantages. Furthermore, the specific advantages of telephone surveys include cost efficient, speed of collecting data, and provide the opportunity of controlling the quality of information gathered. The major disadvantage is the length of interview time because it is difficult to keep an average person on the phone for more than 7-8 minutes. In order to get a high participation rate, the questionnaire was limited to approximately 7-8 minutes.

The sampling frame for the study was developed from the database of the Small Business Development directory of the City of Buffalo, New York. The sample was restricted to the zip codes of 14201, 14202, and 14213 with a total sampling base of 590 micro enterprises. My research budget was limited, in that; I could not afford to sample the entire inner-city of Buffalo.

The survey instrument was pre-tested with a pilot study of 25 firms during September 2009. The results and feedback from the pilot study were used to design the final survey instrument. Telephone interviews were than conducted by professional trained interviewers utilizing the Computer Aided Telephone Interviewing (CATI) system and by computer-assisted random sampling. After three attempts, 68 usable responses were received (yielding an initial response rate of $12 \%$ ). In order to achieve a higher response rate three more attempts were made to the remaining businesses, yielding another 32 additional completed surveys (giving a final response rate of 17\%).

Although response rates of approximately $20 \%$ is common in survey research that focuses on business establishments, the $17 \%$ response rate was disappointing in light of the potential salience of the study to the target firms. Nevertheless, t-tests comparing early $(n=68)$ versus late respondents $(n=32)$ failed to uncover statistically significant differences between the two groups in terms of critical variables such as start-up finances and levels of financing. This said, I openly concede that a $17 \%$ response rate is insufficient to offer conclusive findings. Instead, the results should be treated as suggestive only.

The survey instrument included both qualitative and quantitative questions. Quantitative measurement of the variables ranged from ordinal (5 point Likert scale), categorical (yes/no) to interval (percent of funds borrowed). The first section of the survey instrument obtained information on revenue, employment size, business type and ownership. The second section asked about financial and non-financial assistance and barriers facing the establishment while the third section asked about the goals of their establishment.

\section{CHARACTERISTICS OF THE SURVEY ESTABLISHMENTS}

Our analysis begins with an overview of the characteristics of the micro enterprises across the four size classes of firms as presented in Tables 1 through 4 . As Table 1 indicates, the respondents examined in this survey suggests a balanced percentage between retail and service industry categories of which half report annual sales of less than $\$ 100,000$. The data in Table 2 indicates that about half the micro enterprises are sole proprietorships or partnerships while the other half are either a $\mathrm{C}$ or $\mathrm{S}$ corporation.

The sample statistics also indicate that a fourth of the establishments are fairly young (less than 10 years) while half of them have been in operation for more than 20 years, which is a strong indicator of the longevity and sales volume of micro enterprises. Similarly, the distribution of number of employees reveals that approximately two-thirds of the businesses surveyed have one or two employees which increase with increased sales volume. The statistical data from the survey validate some of the similarities of the characteristics of micro enterprises of innercity Buffalo and other inner-cities across the nation.

Table 1: Industry By Sales Category

\begin{tabular}{|l|c|c|c|c|c|}
\hline & \multirow{2}{*}{$\begin{array}{c}\text { Total } \\
\text { Firms }\end{array}$} & $\begin{array}{c}\text { Less than } \\
\mathbf{\$ 5 0 , 0 0 0}\end{array}$ & $\begin{array}{c}\mathbf{\$ 5 1 , 0 0 0}- \\
\mathbf{\$ 1 0 0 , 0 0 0}\end{array}$ & $\begin{array}{c}\mathbf{\$ 1 0 1 , 0 0 0}- \\
\mathbf{\$ 5 0 0 , 0 0 0}\end{array}$ & $\begin{array}{c}\text { Over } \\
\mathbf{\$ 5 0 0 , 0 0 0}\end{array}$ \\
\cline { 2 - 6 } & $\mathbf{\%}$ & $\mathbf{\%}$ & $\mathbf{\%}$ & $\mathbf{\%}$ & $\mathbf{\%}$ \\
\hline Retail & 41 & 25 & 32 & 56 & 60 \\
\hline Service & 59 & 75 & 68 & 44 & 40 \\
\hline Total Firms & $100 \%$ & $100 \%$ & $100 \%$ & $100 \%$ & $100 \%$ \\
\hline
\end{tabular}


Table 2: Organization Form By Sales Category

\begin{tabular}{|c|c|c|c|c|c|}
\hline & $\begin{array}{c}\text { Total } \\
\text { Firms } \\
\end{array}$ & $\begin{array}{c}\text { Less than } \\
\$ 50,000\end{array}$ & $\begin{array}{l}\$ 51,000- \\
\$ 100,000\end{array}$ & $\begin{array}{l}\$ 101,000 \\
\$ 500,000\end{array}$ & $\begin{array}{c}\text { Over } \\
\$ \mathbf{5 0 0 , 0 0 0} \\
\end{array}$ \\
\hline Sole/Proprietorship/Partnership & 52 & 82 & 64 & 26 & 10 \\
\hline C or S Corporation & 48 & 18 & 36 & 74 & 9 \\
\hline Total Firms & $100 \%$ & $100 \%$ & $100 \%$ & $100 \%$ & $100 \%$ \\
\hline
\end{tabular}

Table 3: Length of Establishment By Sales Category

\begin{tabular}{|l|c|c|c|c|c|}
\hline & Total & $\begin{array}{c}\text { Less than } \\
\mathbf{\$ 5 0 , 0 0 0}\end{array}$ & $\begin{array}{c}\mathbf{\$ 5 1 , 0 0 0}- \\
\mathbf{\$ 1 0 0 , 0 0 0}\end{array}$ & $\begin{array}{c}\mathbf{\$ 1 0 1 , 0 0 0} \\
\mathbf{\$ 5 0 0 , 0 0 0}\end{array}$ & $\begin{array}{c}\text { Over } \\
\mathbf{\$ 5 0 0 , 0 0 0}\end{array}$ \\
\hline & $\mathbf{F i r m s}$ & $\mathbf{\%}$ & $\mathbf{\%}$ & $\mathbf{\%}$ & $\mathbf{\%}$ \\
\hline Less than 10 years & 24 & 32 & 32 & 15 & 10 \\
\hline 11-20 years & 25 & 21 & 27 & 33 & 30 \\
\hline More than 20 years & 51 & 47 & 41 & 52 & 60 \\
\hline Total Firms & $100 \%$ & $100 \%$ & $100 \%$ & $100 \%$ & $100 \%$ \\
\hline
\end{tabular}

Table 4: Employee Size By Sales Category

\begin{tabular}{|l|c|c|c|c|c|}
\hline & Total & Less than & $\mathbf{\$ 5 1 , 0 0 0 -}$ & $\begin{array}{c}\mathbf{\$ 1 0 1 , 0 0 0} \\
\mathbf{\$ 5 0 0 , 0 0 0}\end{array}$ & $\begin{array}{c}\text { Over } \\
\mathbf{\$ 5 0 0 , 0 0 0}\end{array}$ \\
\hline $1-2$ & 64 & 89 & 77 & 37 & 20 \\
\hline $3-5$ & 28 & 11 & 23 & 48 & 40 \\
\hline $6-10$ & 8 & - & - & 15 & 40 \\
\hline Total Firms & $100 \%$ & $100 \%$ & $100 \%$ & $100 \%$ & $100 \%$ \\
\hline
\end{tabular}

\section{FINANCIAL CHARACTERISTICS MICRO ENTREPRENEURS}

Regarding the issues of financing, there are two primary reasons why a micro enterprise owner requires capital. This first reason is to fund the establishment of the business and then to fund for continued business growth. In order for the start-up of the business only one out of ten micro entrepreneurs prepared a formal business plan. (See Table 5). Almost three-fourths needed a start-up financing of less than $\$ 20,000$, while the remaining entrepreneurs needed over $\$ 20,000$ to establish their business. (See Figure 6) The data in Figure 7 indicates that almost half of the micro-owners had to borrow their start-up funds. Given their low levels of income, saving even a small amount of money can be difficult. There are also other factors that do hamper the attempts by the micro enterprise owners to secure financing. Survey findings indicate that majority of the entrepreneurs funded their startup capital requirements from their own personal savings or from other household members. About a third utilized their own savings to finance their business and another third borrowed from friends and family, while only a fourth of them were able to get financing from a commercial financial institution. A third had to borrow more than half of their start-up funds while the remaining borrowed less than a half. Based on the literature (Rutherford, 2000) and the facts it indicates that access to capital is limited for micro enterprise owners for the start-up phase.

Based on these responses the issue arises of the limited use of external capital and whether it is a result of lack of access to external financing resources or the entrepreneur's lack of knowledge on the availability of the public and private financing institutions. A survey conducted by Chandra (2000) indicates that a large majority of the micro entrepreneurs do not use commercial financial institutions because they are limited by lack of access of capital and their poor business conditions. Research results from Haynes et al. (2000) and McPherson (1996) reported that lack of financial assistance is considered to be the main problem facing micro entrepreneurs. In summary, besides commercial financial institutions, the entrepreneur's personal savings and their ability to access financing from friends and family appear to be important source of start-up finance. 
Table 5: Preparation of Business Plan By Sales Category

\begin{tabular}{|l|c|c|c|c|c|}
\hline & $\begin{array}{c}\text { Total } \\
\text { Firms }\end{array}$ & $\begin{array}{c}\text { Less than } \\
\mathbf{\$ 5 0 , 0 0 0}\end{array}$ & $\begin{array}{c}\mathbf{\$ 5 1 , 0 0 0}- \\
\mathbf{\$ 1 0 0 , 0 0 0}\end{array}$ & $\begin{array}{c}\mathbf{\$ 1 0 1 , 0 0 0} \\
\mathbf{\$ 5 0 0 , 0 0 0}\end{array}$ & $\begin{array}{c}\text { Over } \\
\mathbf{\$ 5 0 0 , 0 0 0}\end{array}$ \\
\hline & $\mathbf{\%}$ & $\mathbf{\%}$ & $\mathbf{\%}$ & $\mathbf{\%}$ & $\mathbf{\%}$ \\
\hline Business plan & 12 & 8 & 18 & 7 & 40 \\
\hline No business plan & 88 & 92 & 82 & 93 & 60 \\
\hline Total Firms & $100 \%$ & $100 \%$ & $100 \%$ & $100 \%$ & $100 \%$ \\
\hline
\end{tabular}

Table 6: Start-Up Financing By Sales Category

\begin{tabular}{|l|c|c|c|c|c|}
\hline & $\begin{array}{c}\text { Total } \\
\text { Firms }\end{array}$ & $\begin{array}{c}\text { Less than } \\
\mathbf{\$ 5 0 , 0 0 0}\end{array}$ & $\begin{array}{c}\mathbf{\$ 5 1 , 0 0 0}- \\
\mathbf{\$ 1 0 0 , 0 0 0}\end{array}$ & $\begin{array}{c}\mathbf{\$ 1 0 1 , 0 0 0} \\
\mathbf{\$ 5 0 0 , 0 0 0}\end{array}$ & $\begin{array}{c}\text { Over } \\
\mathbf{\$ 5 0 0 , 0 0 0}\end{array}$ \\
\hline & $\mathbf{\%}$ & $\mathbf{\%}$ & $\mathbf{\%}$ & $\mathbf{\%}$ & $\mathbf{\%}$ \\
\hline Less than $\$ 10,000$ & 60 & 81 & 52 & 48 & 22 \\
\hline$\$ 10,000-\$ 20,000$ & 17 & 11 & 24 & 20 & 22 \\
\hline$\$ 21,000-\$ 40,000$ & 10 & 4 & 14 & 20 & - \\
\hline More than $\$ 40,000$ & 13 & 4 & 10 & 12 & 56 \\
\hline Total Firms & $100 \%$ & $100 \%$ & $100 \%$ & $100 \%$ & $100 \%$ \\
\hline
\end{tabular}

Table 7: Loan Start-up Financing

\begin{tabular}{|l|l|}
\hline Loan at start-up & $47 \%$ \\
\hline No loan at start-up & $53 \%$ \\
\hline Total Firms & $100 \%$ \\
\hline
\end{tabular}

Table 8: Amount Of Start-Up Funds Borrowed

\begin{tabular}{|l|l|}
\hline Less than $10 \%$ & $29 \%$ \\
\hline $11 \%-25 \%$ & $12 \%$ \\
\hline $26 \%-50 \%$ & $27 \%$ \\
\hline $51 \%-75 \%$ & $16 \%$ \\
\hline $76 \%-100 \%$ & $16 \%$ \\
\hline Total Firms & $100 \%$ \\
\hline
\end{tabular}

\section{BARRIERS FACING MICRO ENTREPRENEURS}

In operating their businesses, the micro entrepreneurs encounter serious barriers that impact negatively on their business and profitability. These barriers range from the economy of the city, insurance requirements, to lack of marketing and financial knowledge. Respondents were asked to indicate the problems facing their establishments. Cross tabulation by size and business type did not indicate any significant difference. The economy of the City of Buffalo, and federal, state and city taxes emerged as the primary barriers facing just more than half the respondents. (See Figure 9) This was followed by the availability of reliable labor, liability, workmen's compensation, and disability insurance.

Additional questions posed to the respondents on security and vandalism and their financial and marketing knowledge also presented a barrier for their business operation. The existence of crime and vandalism not only has a negative impact on profitability but can ultimately jeopardize the survival of inner-city businesses with low profit margins. These findings clearly confirm that the economy of the inner-city community and the taxation polices are critical for the success and survival of micro enterprises. 
Table 9: Barriers Facing Micro Entrepreneurs

\begin{tabular}{|l|c|}
\hline & Sample \\
\hline Economy of City of Buffalo & M \\
\hline Federal and State taxes & 3.6 \\
\hline City of Buffalo taxes & 3.5 \\
\hline Liability insurance & 3.0 \\
\hline Finding reliable labor & 2.7 \\
\hline Workmen's compensation/disability insurance & 2.6 \\
\hline Competitors & 2.4 \\
\hline Access to capital & 2.2 \\
\hline Security and vandalism & 2.0 \\
\hline Lack of marketing knowledge & 1.8 \\
\hline Lack of financial knowledge & 1.8 \\
\hline
\end{tabular}

$M$ mean is calculated based on a five-point Likert scale, ranging from: '5-major problem' to '1-not a problem'.

\section{GOALS OF MICRO ENTREPRENEURS}

Majority of the micro entrepreneurs expressed the same feelings regarding their business goals and success factors. The most important goals expressed by these entrepreneurs for the success of their business includes friendly customer service and being financially stable (see Figure 10). The entrepreneurs would like to be able to understand the elements of a financial statement, cash flow, accounts receivables and payables, and inventory management. Also basic marketing knowledge would assist them in maintaining a competitive advantage by product and marketing expansion and communication within their target market area. Lack of marketing and financial knowledge may be a serious impediment for their business operation and restrict their growth potential.

To this end, development policies and training programs must continually be developed and adapted thereby creating a viable policy framework for assisting micro entrepreneurs accomplish their financial and nonfinancial goals and transforming into institutions to address critical issues facing inner-city communities.

Table 10: Goals Of Establishment

\begin{tabular}{|l|c|}
\hline \multicolumn{1}{|c|}{ Goals } & $\begin{array}{c}\text { Sample } \\
\text { M }\end{array}$ \\
\hline Provide better customer service & 4.0 \\
\hline Become financially stable & 3.6 \\
\hline Increase our marketing efforts & 2.8 \\
\hline Become knowledgeable in marketing/sales & 2.6 \\
\hline Undercut our competitor on the basis of non-price factors & 2.2 \\
\hline Become knowledgeable in financial matters & 2.5 \\
\hline Defend ourselves from competitors & 2.5 \\
\hline Expand our product line significantly & 2.2 \\
\hline Become a competitive leader in the community & 2.3 \\
\hline Expand into new locations & 1.8 \\
\hline Undercut our competitor on the basis of price & 1.8 \\
\hline
\end{tabular}

$M$ mean is calculated based on a five-point Likert scale, ranging from '5-Critically important' to '1-not important' 


\section{RESEARCH LIMITATIONS}

Caution should be taken in generalizing the results of this study because this study is subject to several limitations. The three major limitations are: 1) sample size,2) low response rates, and 3) limited geographic scope.

The first limitation concerns the small sample size used in this study. Data was collected from three zip codes instead of the total micro enterprise population in inner-city Buffalo because of the limited budget. A second weakness of the study is the low response rate of 17 percent. Usually a 20 percent or lower response rate in survey research with small businesses is quite common, but nevertheless the response rate of 17 percent is insufficient to provide conclusive findings and thus the results should be treated as suggestive only. Finally, the sample was selected from three zip codes in the inner - city of Buffalo, New York and thus limited in geographic scope.

\section{CONCLUSIONS}

Micro enterprises are considered as an effective policy and strategy to overcome poverty both in developed and developing economies. Furthermore, in communities with low-income, low level educational attainment and high unemployment rates, the creation of micro enterprises and self-employment is viewed as one route out of poverty and reduction of social costs. The Small Business Administration has developed polices which benefit inner-city low-income communities, low educational attainment, high level of unemployment, and a high concentration of minority (Hispanic and African American) population.

For micro-enterprise owners, a major problem is trying to locate funding because of lack of collateral to obtain a loan. Another problem is their lack of knowledge in preparing a business plan, which is an essential document to obtain a loan from a commercial financial institution. The availability of effective financing programs should be considered as an imperative by government institutions. Furthermore, the availability of a wide array of financial and non-financial services are critical for the survival, productivity, and growth of micro enterprises which could lead to economic growth and job creation in inner-city communities.

Increasingly the literature on inner-city development suggests that the development of more micro enterprise led development policies could enable economically disadvantaged inner-city communities to reverse declining conditions by creating jobs and wealth through micro enterprises. Finally, this study has offered an exploratory review of a topic that has attracted significant attention in the recent academic literature on micro enterprise activities and viability in the retail and services sector.

\section{AUTHOR BIOGRAPHY}

Arup K. Sen, Ph.D. is currently the Vice President for Academic Affairs at D'Youville College, Buffalo, New York. His research interest revolves around small and medium-sized enterprises, how and why firms invest, barriers, and opportunities for growth. His teaching interest is in International Business and Marketing.

\section{REFERENCES}

1. Acs, Z.J. and E. Malecki. (2003). Entrepreneurship in Rural America: The Big Picture. Pp. 21-29 in Main Streets of Tomorrow: Growing and Financing Rural Entrepreneur: A Conference Summary, edited by M. Drabenstott, N. Novack and B. Abraham. Kansas City: Federal Reserve Bank, Center for the Study of Rural America.

2. Chandra, V. (2000). Constraints on growth and employment in South Africa: evidence from a SMME firm survey, Washington: World Bank

3. Deutsch, R. ( 2006), New York State Legislatures Joint Fiscal Committee Hearings on Economic Development Policy in the 2005-2006 Executive Budget Proposal, p.14.

4. Dumas, C.,(2001), Evaluating the outcomes of micro enterprises training for low income women; Journal of Development Entrepreneurship, Vol. 6,No.2,August

5. Frey, J.H. (1989). Survey research by telephone, 2 Ed., Sage, Newbury Park, C.A. 
6. Haynes, C.B., K.K. Seawright and W.C. Giauque (2000), 'Moving Microenterprises Beyond a Subsistence Plateau', Journal of Microfinance, vol. 2, no. 2, p. 135-151.

7. Hisrich and Peters (1998) Entrepreneurship (4 ${ }^{\text {th }}$ Edition) Boston. McGraw Hill.

8. Jurik, N., Cavender, G., Cowgill, J. (2006), Searching for social capital in U.S. micro enterprise development programs, Journal of Sociology \& Social Welfare, Vol.XXXIII,3.

9. Lichtenstein, G. A. and T. A. Lyons. (2001). The Entrepreneurial Development System: Transforming Business Talent and Community Economies. Economic Development Quarterly 15 (1): 3-20.

10. McPherson, M.A. (1996), Growth of Micro and Small Enterprises in Southern Africa. Journal of Development Economics, vol. 48, p. 253-277.

11. Nolan, A. (2003) Entrepreneurship and Local Economic Development: Policy Innovations in Industrialized countries. Pp. 77-90 in Main Streets of Tomorrow: Growing and Financing Rural Entrepreneur: A Conference Summary, edited by M. Drabenstott, N. Novack, and B. Abraham. Kansas City, MO: Federal Reserve Bank of Kansas City, The Center for the Study of Rural America.

12. Porter, M.(1995), The competitive advantage of the inner-city; Harvard Business Review,No.73, May-June 55-71

13. Rogers, C., Gent, M., Palumbo ,G., \& Wall, R. (2001), Understanding the growth and viability of inner-city businesses; Journal of Development Entrepreneurship, Vol.6, No. 3 December.

14. Rogerson, C. ( 1996), Rethinking the informal economy of South Africa; Development Bank of Southern Africa.

15. Rutherford, S. (2000), 'Raising the Curtain on the "Microfinancial Services Era", Focus Notes, No. 15, Consultative Group to Assist the Poorest, World Bank, Washington.

16. Sevron, L. (1997), Micro enterprise programs in U.S. inner-cities: economic development or social welfare; Economic Development Quarterly, Vol.11, May.

17. Schreiner, M. (2001), Micro enterprise in the first and third worlds, World Development Bank, Vol.31, No. 9.

18. Shaw, J. (2004), 'Microenterprise Occupation and Poverty Reduction in Microfinance Programs: Evidence from Sri Lanka', World Development, vol. 32, no. 7. 